Mannheimer Manuskripte zu Risikotheorie,

Portfolio Management und Versicherungswirtschaft

Nr. 138

Self-Annuitization, Consumption Shortfall in Retirement and Asset Allocation: The Annuity Benchmark

von

Peter Albrecht and Raimond Maurer

Mannheim 05/2002 


\title{
Self-Annuitization, Consumption Shortfall in Retirement and Asset Allocation: The Annuity Benchmark
}

\author{
Peter Albrecht*) and Raimond Maurer**) \\ *) University of Mannheim, \\ Professor for Risk Theory, Portfolio Management and Insurance \\ D-68131 Mannheim (Schloss), Germany \\ Telephone: 496211811680 \\ Facsimile: 496211811681 \\ E-mail: risk@bwl.uni-mannheim.de \\ **) Johann Wolfgang Goethe University of Frankfurt/Main, \\ Professor for Investment, Portfolio Management and Pension Finance \\ D-60054 Frankfurt/Main, Senckenberganlage 31-33 (Uni-PF 58), Germany \\ Telephone: 496979825227 \\ Facsimile: 496979825228 \\ E-mail: RMaurer@wiwi.uni-frankfurt.de
}

\begin{abstract}
The present paper considers a retiree of a certain age who is endowed with a certain amount of wealth and is facing alternative investment opportunities. One possibility is to buy a single premium immediate (participating) annuity-contract. This insurance product pays a life-long pension payment of a certain amount, depending e.g. on the age of the retiree, the operating cost of the insurance company and the return the company is able to realize from its investments. The alternative possibility is to invest the single premium into a portfolio of mutual funds and to periodically withdraw a fixed amount that is assumed to be equivalent to the consumption stream generated by the annuity. The particular advantage of this self annuitization strategy compared to the life annuity is its greater liquidity and the possibility of leaving out money for heirs. However, the risk of self annuitization is to outlive assets before the uncertain date of death. The risk can thus be specified by considering the probability of running out of money before the uncertain date of death. The determination of this personal probability of consumption shortfall with respect to German insurance and capital market conditions is the objective of this paper.
\end{abstract}

This research was supported by the German Science Association (Deutsche Forschungsgemeinschaft), SFB 504, University of Mannheim. Parts of the paper have been elaborated while the second author was a Metzler Visiting Professor at the Wharton School. The authors are grateful to Ivica Dus for excellent research assistance and to the German Investment Association (Bundesverband Deutscher Investmentgesellschaften) for support in data collection. The authors would like to thank Andrew Cairns, Steven Haberman, Olivia Mitchell, Alex Muermann, Michael Orszag, and the three anonymous referees for very valuable comments and suggestions. Opinions remain solely those of the authors. 


\section{Introduction}

Reaching retirement raises the question how to draw down assets that individuals have accumulated during working live. A traditional and common vehicle, is to purchase life annuities, which are sold by insurance companies. In exchange for a nonrefundable premium typically paid as a lump-sum at the date of purchase the insurance company promises to make a series of periodic payments to the annuitant contingent on the event that he or she survives. In general these payments may be fixed in nominal terms (fixed annuity), rising at a prespecified fixed nominal escalation rate (grade annuity) or indexed to inflation (real annuity). They may reflect the return of a specific asset portfolio that backs the (variable) annuity or depend on the insurance company's experience with mortality, investment returns and expenses (participating annuity). ${ }^{1}$ As Mitchell et al. (1999) pointed out, the main characteristic of the life annuity is that it protects the annuitant against the risk of outliving accumulated savings in retirement by pooling longevity risk across a group of annuity purchasers. While life annuities provide invaluable longevity insurance that cannot be replicated by pure investment vehicles, there are also disadvantages that come along with annuitization: First, there is a serious loss of liquidity, because (in general) assets cannot be recovered after purchase of the annuity, regardless of special needs. Second, in its simplest form where income payments are contingent on an individual's survival there is no chance leaving out money for heirs even in the case of an early death of the annuitant. ${ }^{2}$

As an alternative there is the possibility of a strategy which may be called self-annuitization. ${ }^{3}$ Such a self-constructed annuity consists of investing at retirement an initial endowment of wealth amongst the various asset categories (e.g. equity, bonds, real estate) typically represented by a family of mutual funds, earning a stochastic rate of return, and withdrawing periodically a fixed amount for consumption purposes. The particular advantage of the self annuitization strategy compared to the life annuity is the greater liquidity and the possibility of bequeathing some of the funds in the case of an early death. However, drawing income directly from individual mutual fund accounts provides no pooling of longevity risk. Therefore, in the case of fixed periodic withdrawal from the funds the retirees can outlive their assets before the uncertain date of death in the event of long-run low investment returns connected with longevity. 
A number of papers ${ }^{4}$ analyze the risk/return-profiles of self-annuitization strategies. Both risk and return are crucially dependent on the amount that is periodically withdrawn from the fund as well as the fund asset allocation, i.e. the investment weights in equity, bonds and real estate assets. The choice of an appropriate benchmark for the withdrawal amount as well as the corresponding optimal asset allocation of the funds, however, are still open questions. The main new feature of the present paper is to choose as a benchmark not a more or less ad hoc withdrawal rate, but the withdrawal amount generated by a typical (at least for the German market) annuity itself. We call the resulting strategy of self-annuitization using mutual funds the insurance equivalent fund withdrawal-plan. With respect to this benchmark, the main objective $^{5}$ of the paper is to find the asset allocation of the mutual fund which minimizes a specific measure ${ }^{6}$ of the risk of the retiree, the probability of running out of money before the uncertain date of death (probability of consumption shortfall). Generally we assume representative conditions (with respect to products, expenses, pricing, etc.) as to be found in the German annuity market as well as in the German mutual funds market. Another specific feature to be considered in the analysis stems from the fact that German annuity contracts are of the participation type, which means that only a certain part of the annuity promised is guaranteed. The remaining part is at least in principle subject to the amount of profit participation and thus depends on the investment performance (surplus strength) of the insurance company offering the life-annuity contract. We therefore perform a sensitivity analysis with respect to the promised amount of the benchmark annuity.

\section{Data Base and Research Design}

The German life insurance market has only been deregulated since 1994. That is why innovative insurance products (e.g. unit-linked insurance contracts, variable annuities) have rather small market shares. In this paper we therefore concentrate ourselves on traditional products, which are of the participation type. Premiums (and as well the premium reserve) of participating life insurance policies are traditionally calculated "on the safe side" using a socalled first order technical basis. This implies, for example, using a conservative technical interest rate ("first order interest rate"), which is lower than the expected return on the invested assets. In this way margins of safety are built into the valuation elements to allow for protection for adverse deviations. The first order interest rate is guaranteed ${ }^{8}$ for the entire lifetime of the contract, which means, that the premiums invested have to earn a 
corresponding minimum return year by year. This first order interest rate is limited by regulation. Because premiums are calculated in a conservative way life insurance companies earn a systematic surplus. A large proportion of the surplus, however, usually has to be distributed to the policyholders. In Germany the distribution of surplus ${ }^{9}$ is regulated by the supervising authority. For single-premium immediate annuities, this means that there is some guaranteed annuity and an annuity resulting from surplus. The latter is not guaranteed but calculations based on expected future surplus rates are used when the product is marketed. For this reason insurance companies have a strong interest in keeping surplus rates stable. This is achieved by "return smoothing", which is performed by accumulating hidden reserves in "good" years (i.e. years in which the return on invested assets is above average) and using these reserves to preserve the surplus in years where the insurance companies earn less from investment.

In our analysis, we assume that a constant annuity (including surplus) will be paid throughout the life of the contract. Using the standard actuarial present value approach (cf. appendix A) there is an equivalent interest rate (the so-called "second order interest rate") to every constant annuity amount specified - and vice versa. This second order interest rate is one of the central tools in our analysis. The second order interest rate ${ }^{10}$ is determined on the basis of a realistic estimation of the long run return of insurers assets and is the standard interest rate used to determine the annuity promised. The second order interest rate is in principle subject to (partial) revision in case of adverse developments on the asset side. However, there is a lower bound to possible revision, which is equal to the first order interest rate. As a consequence the variation of the second order interest rate performed in this contribution is equivalent to a variation of realistic annuity amounts under German market standards and allows to take into consideration the various surplus strengths of the insurance companies offering the annuities. Additionally the problem that the envisioned benefit payments are not guaranteed in full, can be covered. A reduction in the benefit amount can be represented in the model by using a lower second order interest rate.

The benchmark against the insurance equivalent fund withdrawal-plan is evaluated therefore is the payout stream generated by a single-premium, immediate, individual participating life annuity policy from a (German) commercial life insurance company. Using the actuarial principle of equivalence, we estimate the price of the annuity by calculating the present value of expected benefits paid to the annuitant including expense loadings (e.g. commissions, 
administration fees) the annuity provider has to cover. Therefore, assumptions about mortality risk and the age of the annuitant, the interest rate used by the insurance company to discount expected benefit payments, and the cost-structure of the insurance company are necessarily to be made.

With regard to the specification of the biometrically dependent parameters of the insured, we take the DAV (German Actuarial Association) basic annuitant mortality table 1994 R (c.f. appendix A) into consideration. Hereby, a man with an retirement entry age of 60, 65 and 70 was considered, respectively. For each case, constant benefits paid at the beginning ${ }^{11}$ of each year the individual is alive, based on the assumption of a second order interest rate of $4 \%$, $5,5 \%$ and $7 \%$ respectively, were calculated for a lump-sum premium of EUR 100 using the calculation formula in Appendix A. Regarding the cost-structure of the insurance company, it is assumed that the total expense loading relative to the pure actuarial premium is about $7,12 \%$ which corresponds to the usual market conditions in Germany for single premium annuity policies (see Appendix A for technical details). Accordingly, one obtains the following yearly income payments per EUR 100 of premium (before personal income taxes):

\section{TABLE 1}

In order to maintain the comparability of the two investment strategies for retirement, the life annuities shown in Table 1 will serve as benchmarks for the evaluation of capitalexhaustion risks of alternative investment fund withdrawal-plans in the further course of this paper. For an identical amount of initially invested capital (especially considering the sales loads in the case of an investment in a mutual fund) the annual withdrawal from the fund corresponds to those of the respective parameter-constellations of the life annuity as reported in Table 1 (insurance equivalent fund withdrawal-plan).

The probability of a consumption shortfall (respectively: probability of asset exhaustion), which results when an individual outlives his wealth will be regarded as the central risk index for the previously depicted "insurance equivalent" fund-solution. We use Monte-Carlo simulations based on the historical experience of mutual funds in the German market to predict this probability. ${ }^{12}$. The stochastic dynamics of the (uncertain) market values of investment fund units are modeled as a (three-dimensional) geometric Brownian motion with constant drift, diffusion and correlation parameters. For the estimation of these parameters, we 
use the historical investment returns (including capital gains and dividends) for German mutual funds over the period 1980-1998. Three classes of well diversified funds have been studied: stocks, bonds, and real-estate funds concentrating their assets mainly within the German capital and real estate market. According to usual market conditions in the German mutual fund market, the sales charges are 5\% for stocks and real-estate funds and $3 \%$ for bond funds and the withdrawal charges are ero in all cases. ${ }^{14}$ Proceeding from a sample of 17 stock funds, 23 bond funds and 7 realestate funds we chose the fund which, as regards the average return over the period 1980-1998, took the median position. The yearly time-series returns from the years 1980 till 1998 give the following estimates for the mean log return p.a., the volatility and the correlation-coefficients:

\section{TABLE 2}

With respect to these parameters and from the respective entry-age (i.e. 60, 65 and 70) up to the end-age of 110 in total 100.000 simulations were generated to obtain the personal probability of consumption shortfall (PCS) for the insurance equivalent investment fund withdrawalplan.

One may argue that the correlations between the second order interest rate and the capital markets, especially the bond market are ignored in the analysis. Obviously the second order interest rate is variable over long time horizons. If the interest rates earned by bonds systematically get lower because of lower inflation rates and stock markets earn a lower risk premium even return smoothing can cushion the impact of these changes only for a while. On the other hand, we have fixed the evaluation period both for the second order interest rate (cf. section 3.4) and for the investment funds analyzed. Therefore we are comparing all markets, insurance as well as capital markets "under the same conditions". Systematically lower bond and equity returns would not only change the second order interest rate but also the return characteristics to be used in the analysis. Furthermore, as we analyze second order interest rates of $4 \%, 5,5 \%$ and $7 \%$, not only the second order interest rates typical for the evaluation period (which are slightly above 7\%, cf. section 3.4) are considered but also the guaranteed first order interest rate (which was $4 \%$ during the evaluation period). 


\section{Results of the Simulation Studies}

\subsection{Withdrawal-plans for Individual Funds}

We start with the special case of a $100 \%$ investment in the stock fund. The corresponding PCS depending on the amount of second order interest rate are included in the following figure.

\section{FIGURE 1}

It is recognized that the probability of consumption shortfall increases the higher the second order interest rate chosen for the calculation of the annuity is. In other words, the better the investment performance of the insurance company (as measured by the second order interest rate for annuity calculation), the higher the risk for a comparable investment withdrawalplan. It is evident that for a (hypothetical) second order interest rate of $4 \%$, the corresponding probability of $4,38 \%$ is a rather moderate. This probability can be interpreted such that in 438 of 10.000 possible future capital market situations the 60 -year old pensioner who invested his initial capital $100 \%$ in a stock fund, survived the exhaustion of the fund capital.

As a second special case, a 100\% investment in bond funds has been studied. The corresponding probabilities of consumption shortfall during the lifetime of the pensioner, once again dependent on the second order interest rate chosen, are shown in figure 2.

\section{FIGURE 2}

In comparison to a $100 \%$ investment in a stock fund, there is a significantly lower risk of consumption shortfall for a bond fund with a second order interest rate of $4 \%$. However, the corresponding probabilities for a yield of 5,5\% and $7 \%$ with a $100 \%$ investment in the bond fund are clearly higher than with a $100 \%$ investment in a stock fund. This may be explained as follows: the probability of outliving wealth in the fund case depends on the expected return of the fund, the extent of return volatility as well as the amount of the insurance equivalent withdrawals (as represented by the second order interest rate for annuity determination).

In the case of the stock fund, the risk of asset-exhaustion during the lifetime of the pensioner is dominated by the volatility of fund returns. In the case of the significantly less volatile bond fund, the likelihood of asset-exhaustion is much more strongly determined by the expected fund return and less by its volatility. From a withdrawal amount represented by a second order interest rate of 5,5\% onwards a $100 \%$ investment in a bond fund is therefore - at least with 
regards to the PCS - less advantageous relative to a $100 \%$ stock investment. This amount of pension withdrawal implies competitive advantages for the investment alternative which is riskier, but also generates higher expected returns. In the case of lower pension withdrawals (represented by a second order interest rate of $4 \%$ ) the conditions are however reversed, as the less risky and lower return investment becomes more attractive.

\section{FIGURE 3}

Figure 3 reflects the case of a $100 \%$ investment in a realestate fund. It shows that in the case of a high second order interest rate, a similar situation appears as in the previous example. There is an even lower risk $(1,56 \%)$ for a pure realestate based insurance equivalent withdrawalplan and an interest rate of $4,0 \%$, compared with the previous evaluations. However, this risk rises strongly at a second order interest rate of 5,5\%. In the case of a second order interest rate of $7 \%$, there is even a capitalexhaustion risk of $61,54 \%$. These extreme values can be explained as follows: as Table 2 shows, the expected average return on a real-estate fund share is $6,62 \%$ p.a. whereby the very low volatility of $1,78 \%$ shows that these returns are very stable over time. In addition Table 1 shows, that using an interest rate of $4 \%$ the annuity pays $6,23 \%$ in the case of a 60 -year old man. The very stable return paid on fund-capital lies then 39 points above the annuity payments. Therefore the determined benchmark returns can in most cases (i.e. simulated paths) be realized from the current interest on the real-estate fund shares, without having to reduce the existing fund capital. For higher second order interest rates the expected realestate returns are however consistently below the benchmark. Thereby, in order to make up the difference, the fund capital must be reduced.

\subsection{Diversification Effects through Asset Allocation}

The previous evaluations have neglected the central result of modern portfolio theory according to which (under certain conditions), risk diversification effects may be taken advantage of through the appropriate mixture of investment alternatives. A diversification effect occurs when the risk of the entire portfolio is lower than that of the risk-minimizing individual investment. A necessary condition for the appearance of a diversification effect is that the respective individual investments are not perfectly correlated. A glance at Table 3 
shows that the correlation coefficients between the individual classes of funds are in all cases significantly different from one and in some cases even negative.

In order to attain an optimal diversification potential, i.e. a maximal risk-reduction relative to a $100 \%$ investment in each of the funds, it is necessary to have a systematic selection procedure for the relative investment weights in the individual funds. For the determination of the risk-minimizing static asset mix of stocks, bonds and realestate funds, the investment weights are varied by increments of $5 \%$.

To graphically illustrate the diversification effect, the probability of consumption shortfall during the lifetime of the pensioner is shown in the following figures for alternative fund allocations from at first two classes of funds (i.e. stocks and bonds) only. Hereby the assumed entry-age was 60 years, and the second order interest rate chosen for the calculation of the annuity was varied between $4 \%, 5,5 \%$ and $7 \%$.

\section{FIGURE 4}

Figure 4 gives insight into the influences of varying fund composition as well as a varying amount of the second order interest rate on the capitalexhaustion risk. It is likewise evident that the probability of asset-exhaustion during the lifetime of the pensioner is higher, the higher the second order interest rate chosen for the calculation of the annuity. The shape of the curve shows additionally that there is an optimal stock fund proportion (and/or bond fund proportion) in which the risk of consumption shortfall is minimal and/or where the diversification potential is exploited optimally. The "risk-minimizing" stock proportion is higher, the higher the second order interest rate is. The corresponding minimal probabilities of consumption shortfall are presented in Figure 5:

\section{FIGURE 5}

\section{FIGURE 6}

In Figure 6 the resulting probabilities of consumption shortfall dependent on the second order interest rate for annuity determination on the one hand and on the basis of a risk-minimizing fund allocation of stock, bond and realestate funds on the other are shown. Once again, the 
results make clear that the amount of the periodic pension-withdrawal and thereby the amount of the surplus strength of the insurance company offering the policy are the main determinants with regards to a substantial size of the probability of asset-exhaustion during the lifetime of the pensioner. In the area of a second order interest rate of 4,0\% and 5,5\% the probability of capitalexhaustion is low to moderate, for $7 \%$, however, it is much more substantial.

To summarize, the respective probabilities of a consumption shortfall as well as the riskminimizing fund allocations for a 60-, 65- and 70-year old pensioner are represented in the following table.

\section{TABLE 3}

First of all we note that in the case of 65- and 70-year old pensioner, the respective probabilities of capitalexhaustion during his lifetime reach a uniformly higher level in comparison to the case of the 60-year old pensioner. It is without doubt that independently of the chosen second order interest rate in the risk-minimizing situation, an increase in the stockproportion occurs in each case. Apparently the relatively high amount of the insurance equivalent pension, due to the shorter remaining lifespan of the 65 and 70-year old pensioner, requires a higher involvement in the more profitable investment of the stock-fund in each case. This in turn involves however a higher risk-level in each case. The 70-year old pensioner has to accept substantial probabilities of capital-exhaustion within his lifetime relying on an insurance equivalent fund solution.

If one looks at the relative investment weights of stock-units, the following results are obtained: the higher the entry-age and the higher the chosen second order interest rate, the higher the proportions of stocks in the risk-minimizing fund allocation. At a second order interest rate of $7 \%$ stocks are clearly the dominating class of investment. A similarly clear tendency, however in comparison with stocks displaying an opposite trend, may be observed for the realestate and/or bond fund units. The lower the entry-age, and the lower the second order interest rate, the higher the proportions of shares are. To that extent the bond and realestate funds take on the roles of risk stabilizers and stock funds take on the role of yieldincreasers. The following table summarizes the results in compact form.

\section{TABLE 4}




\subsection{A Note on the After-tax Case}

The analysis in the present paper ignores taxes. However, annuities on one hand and stock, bond and real estate mutual funds are all taxed rather differently. Tax authorities consider an annuity payment as consisting of two portions. One part is used to pay back the invested amount of capital, this part is not subject to taxation. The second part (depending for instance on the age of the retiree) is considered as interest and thus is taxed. However, the assessment of the taxable portion by the tax authorities is based on a rather approximate procedure. With respect to mutual funds, dividends, interest payments and rental income are taxed, the gains from increasing prices, however, are not. This means, that the tax laws favour an investment in stocks.

Summing up, the consideration of taxes must have an influence of the result of the analysis performed. A detailed analysis will be done in a different exploration.

For the sake of completeness, however, we will summarize the main findings of our preliminary calculations in the following. A first structural result is that the risk minimizing fund allocation gives more weight to stocks when taking taxes into account. The proportion of stocks increases with tax rate, retirement age and second order interest rate assumed. The second structural result follows from the first. The probabilities of consumption shortfall for the risk minimizing fund allocation will in general be even (moderately) higher than in the case before.

\subsection{Empirical Order of Magnitude of the Second Order Interest Rate for German Life Insurers}

The previous mainly hypothetical assumptions regarding the second order interest rate will now be supplemented with empirical information. The decisive factor for the order of magnitude of the second order interest rate is the long-term return from the capital investment of the respective insurance company. For this purpose we collected the yearly net investment returns on book value basis ("Nettoverzinsung") reported in the accounting statements of the 30 largest German life insurers (which represented about $75 \%$ of the German life insurance market measured by premium volume) covering the time period from 1980 to 1998. For each 
of the thirty time series the average log-return, the volatilities and the sample autocorrelations are calculated. Table 5 reports the statistics for the companies with the lowest, average and highest mean return over this time period.

\section{TABLE 5}

Looking at the mean returns, it can be observed that the market is characterized by a very high degree of homogeneity. Among the 30 largest German life-insurers evaluated within the framework of the study, the one with the lowest (highest) average return over this time-period showed a value of $6,85 \%(7,50 \%)$.

Looking at the standard deviations, it can be observed that the investment returns in the German life ins urance market are very stable over time. The volatility of investment returns ranges from $0,25 \%$ to $0,86 \%$ p.a. for the company with the lowest/highest mean return in the sample. In addition, the first order sample autocorrelation of the yearly returns to German life insurance companies is high and reliably statistically distinguishable from zero. It is well known, that return series with these statistical properties, i.e. low volatilities and a high level of serial correlation, are due to temporally smoothing. The same is true for the investment returns for German life insurance companies, which can use several smoothing vehicles. The asset holding by the insurance company is evaluated on a book-value rather than on marketvalue basis. Therefore, it is possible to smooth the investment returns over time by using explicit or hidden reserves. In addition, a substantial part of the investment accounts of a life insurance company is invested in special non marketable fixed coupon bonds (so called "Schuldscheindarlehen"). In general, these bonds are issued at par according to the current level of interest rate of traded government bonds with comparable duration. In contrast to traded corporate or government bonds, the book value of these bonds does not fall if the general interest rate level in the market increases. Therefore, as long as these bonds are not sold they are protected from price risk resulting from movements of the term structure of interest rates. In contrast to this, the assets holding by mutual funds are determined according to market values in the stock or bond market that adjusts rapidly to changes in information and expectations. ${ }^{15}$

Despite the fact that the risk level of the investment returns of German life insurers seems compared to financial instruments traded on capital markets (probably artificially) low, for 
annuitants of the insurance company the smoothed return is the actual holding period return which they receive. Note, because of the specific financial characteristics of a life annuity contract (loss of bequest and liquidity) the reported average returns are not the expected return for a potential investor who is willing to buy annuities as a short term investment.

\section{$4 \quad$ Discussion of Results}

In the present paper, the annuity amount of an annuity contract offered by life insurance companies according to German market standards was chosen as a specific benchmark for evaluating the strategy of self-annuitization. The result obtained are therefore strongly connected to these characteristics.

A first factor lies in the fact that German life insurers earn a net investment return on a book value basis, which is comparatively high on average (during the period of 1980-1998 approximately equal to the mean return of the median bond funds), but at the same time extremely stable (during the period 1980-1998 approximately $8,5 \%$ of the volatility of the median bond funds). This results in a high second order interest rate for the determination of the annuity amount promised.

A second, even more important factor lies in the fact that when choosing the insurance annuity option the retiree implicitly is faced with the trade-off between the achievable annuity amount and the bequest potential. By giving up the bequest potential - which allows an insurance company the pooling of longevity risk over a group of individuals - he is able to realize a substantial increase in the annuity amount. The magnitude of this "mortality credit" can be demonstrated by comparing the streams of income payments of an immediate, fixed life annuity with an immediate term certain annuity. In contrast to a life annuity, where future income payments to the beneficiaries are contingent on the event that the annuitant survives, the term annuity makes payments to the beneficiaries until a specified date, even if the annuitant dies during this time. The periodic payments of such a "deterministic selfannuitization" strategy are calculated under the condition of exactly exhausting at the age of 110 (which is equal the maximum life span in the DAV $1994 \mathrm{R}$ mortality table for life annuity calculation) and an individually accumulated capital of EUR 100 by using 
deterministic interest rates of $4 \%, 5,5 \%$ resp. $7 \%$ to discount future payments. The results are shown in table 6:

\section{TABLE 6}

The differences in the respective entries in Table 1 and Table 6 quantify the annuity spread ("mortality credit") after insurance loads which is due to giving up the bequest potential. When a retiree dies, this benefits the remaining group of annuitants. The resulting annuity spread is quite substantial, e.g. in the case of a 60-ages old retiree and an assumed interest rate of $4 \%$ it amounts to EUR 1.75 , which is nearly $40 \%$ of the annuity amount of EUR 4.4799 in case of deterministic self-annuitization. Moreover, because the probability of survival decreases with the age of the annuitant the mortality credit increases with increasing entry age.

Both factors discussed influence the amount of the insurance equivalent withdrawal, which as a whole is relatively high, especially for high entry ages. This increases the risk of the insurance equivalent fund withdrawal-plan of not earning the withdrawal amount. One point of the method applied that can be seen critically is that there appears to be no (explicit) connection between the development of the stock/bond/real estate markets (directly influencing the mutual funds return) and the investment return of the life insurance company (influencing the second order interest rate and the insurance equivalent withdrawal amount). However, adverse influence of the capital markets on insurance investment returns are partly covered by the variation of the second order interest rate considered. In addition, a look at the simulations reveals that only a small proportion of the ruin probabilities results from highly adverse developments in the mutual fund returns. The larger part is caused by exhausting wealth under "regular conditions". Finally and most important German life insurance companies apply substantial return smoothing using (explicit or hidden) reserves. Therefore, it is reasonable to assume that these reserves are high enough to cover at least medium term adverse return developments in the capital markets. 


\section{Conclusions}

In the present paper, the probability of consumption shortfall during the lifetime of a pensioner for fund withdrawal plans with insurance equivalent withdrawal amount has been studied. Static asset mixtures of stock, bond and real-estate funds were considered. As a main result the following was ascertained: in comparison to private annuity products a self annuitization strategy using mutual fund withdrawal plans contains, in particular for high entry-ages, a substantial risk of outliving the individuals wealth, as long as the benchmark (the annuity) is based on a competitive investment return. It should be kept in mind when assessing the results, that in this study personal risk of consumption shortfall was considered as the primary concern ${ }^{16}$. Possible return implications, such as the bequest potential resulting from fund investment in the event of an early death, or the possibility of additional withdrawals from the fund as well as the greater flexibility of the self annuitization strategy, were not considered. 


\section{Appendix A: Actuarial Foundations of Annuity Calculation}

We consider the following general basic situation. An $x$-year old retiree buys a life-long annuity insurance (taking immediate effect upon advance payment) having paid a single premium $C$. In return, he receives at time $t=x, x+1, \ldots, w$ payments of $R_{0}, R_{1}, \ldots, R_{w-x}$. Here, $\mathrm{w}$ (in Germany presently $\mathrm{w}=110$ ) represents the highest age considered for premium calculation. The (deterministic) rate of interest used by the insurance company to discount future expected cash flows is denoted by $\mathrm{i}\left(\mathrm{q}:=1+\mathrm{i}, \mathrm{v}:=\mathrm{q}^{-1}\right)$. With respect to a table with mortalities $\mathrm{q}_{\mathrm{x}}$ the quantity $\mathrm{p}_{\mathrm{x}}$ denotes the conditional probability that a man aged $\mathrm{x}$ will attain age $\mathrm{x}+\mathrm{t}$.

The actuarial present value of the life annuity (PVA) is then given by (in probabilitytheoretical or alternatively, in actuarial notation):

$$
\begin{aligned}
\operatorname{PVA}(\mathrm{i}) & =\sum_{\mathrm{t}=0}^{\mathrm{w}-\mathrm{x}} \mathrm{R}_{\mathrm{t}} \cdot{ }_{\mathrm{t}} \mathrm{p}_{\mathrm{x}} \cdot \mathrm{V}^{\mathrm{t}} \\
& =\frac{1}{\mathrm{D}_{\mathrm{x}}} \cdot \sum_{\mathrm{t}=0}^{\mathrm{w}-\mathrm{x}} \mathrm{R}_{\mathrm{t}} \cdot \mathrm{D}_{\mathrm{x}+\mathrm{t}} .
\end{aligned}
$$

In the case in which the benefit payment $R_{\varepsilon} \equiv R$ is fixed per unit of time the expression (A1) simplifies to

$$
\operatorname{PVA}(\mathrm{i})=\mathrm{R} \ddot{\mathrm{a}}_{\mathrm{x}}
$$

where

$$
\begin{aligned}
\ddot{a}_{x: n} & :=\sum_{t=0}^{n-1}{ }_{t} p_{x} \cdot v^{t} \\
& =\frac{1}{D_{x}} \cdot \sum_{t=0}^{n-1} D_{x+t}
\end{aligned}
$$

and

$$
\ddot{a}_{x}:=\ddot{a}_{\bar{x}: w+1-x} .
$$

The individual net single premium (i.e. the pure actuarial premium) NSP $=\mathrm{NSP}(\mathrm{i})$ corresponds to PVA(i) and therefore the annuitization of the investment amount $\mathrm{C}$ results in an amount of $\mathrm{R}=\mathrm{R}(\mathrm{i})$ on the basis of solving the equation $\mathrm{BWR}(\mathrm{i})=\mathrm{C}$, and is given by 


$$
R=\frac{C}{\ddot{a}_{x}} \text {. }
$$

Considering gross premiums, we have to modify the approach. The German cost system in life insurance traditionally is using $\alpha$-costs (acquisition costs), $\beta$-costs (renewal commission) and $\gamma$-costs (management expenses) as expense loadings to the net premium. The $\alpha$-costs resp. $\beta$-costs are in percent of the amount of the gross single premium GSP and the $\gamma$-costs are in percent of the annuity per year of the yearly pension payments. In total, the equation $\mathrm{GSP}=\mathrm{NSP}+(\mathrm{a}+\beta) \cdot \mathrm{GSP}+? \cdot \ddot{\mathrm{a}}_{\mathrm{x}} \cdot \mathrm{R}$, results in a gross single premium of

$$
\mathrm{GSP}=\mathrm{R} \cdot \frac{\ddot{\mathrm{a}}_{\mathrm{x}} \cdot(1+?)}{1-\mathrm{a}-\beta}
$$

Assuming that $\alpha=4 \%, \beta=1,25 \%$ and $\gamma=1,5 \%$ we get a total expense loading factor of 1.0714. By using an interest rate i to discount future expected cash flows an annuitization with an investment amount $\mathrm{C}$ leads to a life-long constant pension $\mathrm{R}=\mathrm{R}(\mathrm{i})$ equal to

$$
R=\frac{C \cdot(1-a-\beta)}{\ddot{a}_{x} \cdot(1+?)} .
$$

The DAV-mortality table 1994 R (c.f. Schmithals/Schütz 1995) is conceived on the basis of the mortalities $\mathrm{q}_{\mathrm{x}}{ }^{\mathrm{B}}$ of the basic mortality table 2000 and the trend function $\mathrm{F}(\mathrm{x})$ as a twodimensional mortality table of the form

$$
\mathrm{q}_{\mathrm{x}}^{\mathrm{t}}=\exp \{-\mathrm{F}(\mathrm{x}) \cdot(\mathrm{t}+\mathrm{x}-2000)\} \cdot \mathrm{q}_{\mathrm{x}}^{\mathrm{B}}
$$

Hereby $\mathrm{q}_{\mathrm{x}}{ }^{\mathrm{t}}$ corresponds to the mortality of an $\mathrm{x}$-year old man, born in year $\mathrm{t}$. For the evaluations in the recent paper, we have proceeded on the assumption that the studied person of a fixed pension entry-age (e.g. 60, 65, 70 ) will reach this age in the year 2000. The relevant $\mathrm{q}_{\mathrm{x}}$ therefore corresponds to the respective amounts in the basic table 2000, i.e. $\mathrm{q}_{\mathrm{x}}=$ $\mathrm{q}_{\mathrm{x}}^{\mathrm{B}}$. 


\section{Appendix B: Determination of the Probability of Consumption Shortfall}

Let $\left\{V_{R}(t) ; t \geq 0\right\}$ represent the accumulation process of the value of an initial capital amount $\mathrm{C}$ invested at the time $\mathrm{t}=0$ whereby a constant yearly pension payment $\mathrm{R}$ is withdrawn from the accumulating wealth at the beginning of each year (i.e. at $t=0,1,2, \ldots$ ). Let $T_{x}$ represent the curtated remaining lifetime of an xyear old pensioner at $t=0$, the point in time of the investment.

The event $V_{R}(u) \leq 0$ reflects an exhaustion of the invested capital at the point in time $t=u$. Formally, we are interested in the earliest of these points in time (the point in time when a consumption shortfall occurs), i.e.

$$
\tau_{\mathrm{R}}=\inf \left\{\mathrm{u}>0 ; \mathrm{V}_{\mathrm{R}}(\mathrm{u}) \leq 0\right\}
$$

Obviously, we have $\mathrm{V}_{\mathrm{R}}(\mathrm{u}) \leq 0$ for $\mathrm{u}=\tau_{\mathrm{R}}$. The point in time $\tau_{\mathrm{R}}$ is uncertain and depends on the respective development-path taken by the asset process.

At the centre of interest is the situation $T_{x}>\tau_{R}$, i.e. if wealth-exhaustion takes place when the observed person is still alive. In particular, the probability $\operatorname{PCS}(\mathrm{R})$ of this event is of relevance, whereby

$$
\operatorname{PCS}(\mathrm{R}):=\mathrm{P}\left(\mathrm{T}_{\mathrm{x}}>\tau_{\mathrm{R}}\right)
$$

For the derivation of PCS we deduce the following sequence of equations that are based on the assumption that $T_{x}$ and $\tau_{R}$ are stochastically independent:

$$
\begin{aligned}
\mathrm{P}\left(\mathrm{T}_{\mathrm{x}}>\mathrm{t}_{\mathrm{R}}\right) & =\mathrm{P}\left(\mathrm{T}_{\mathrm{x}}-\mathrm{t}_{\mathrm{R}}>0\right) \\
& =\sum_{\mathrm{t}=0}^{\infty} \mathrm{P}\left(\mathrm{T}_{\mathrm{x}}-\mathrm{t}>0 \mid \mathrm{t}_{\mathrm{R}}=\mathrm{t}\right) \cdot \mathrm{P}\left(\mathrm{t}_{\mathrm{R}}=\mathrm{t}\right) \\
& =\sum_{\mathrm{t}=0}^{\infty} \mathrm{P}\left(\mathrm{T}_{\mathrm{x}}>\mathrm{t}\right) \cdot \mathrm{P}\left(\mathrm{t}_{\mathrm{R}}=\mathrm{t}\right) \\
& =\sum_{\mathrm{t}=0}^{\infty}{ }_{\mathrm{t}} \mathrm{p}_{\mathrm{x}} \cdot \mathrm{P}\left(\mathrm{t}_{\mathrm{R}}=\mathrm{t}\right) \\
& =\sum_{\mathrm{t}=0}^{\mathrm{w}-\mathrm{x}}{ }_{\mathrm{t}} \mathrm{p}_{\mathrm{x}} \cdot \mathrm{P}\left(\mathrm{t}_{\mathrm{R}}=\mathrm{t}\right) .
\end{aligned}
$$


If one, for the present purposes, excludes the case $R>C$, i.e. $\tau_{R}=0$, we finally obtain the following result:

$$
\operatorname{PCS}(\mathrm{R})=\sum_{\mathrm{t}=1}^{\mathrm{w}-\mathrm{x}}{ }_{\mathrm{t}} \mathrm{p}_{\mathrm{x}} \cdot \mathrm{P}\left(\mathrm{t}_{\mathrm{R}}=\mathrm{t}\right)
$$

The advantage of this representation lies in the separation of the mortality law on the one hand, and the constellation of asset-exhaustion at a fixed point in time on the other. The mortality law is given by the DAV-mortality table $1994 \mathrm{R}$. The probabilities $\mathrm{P}\left(\tau_{\mathrm{R}}=\mathrm{t}\right)$ however, will be determined by Monte-Carlo-Simulation. 


\section{Appendix C: Process of Funds-Investment: The Case of Stocks and Bonds}

Let $\left\{\mathrm{V}_{\mathrm{R}}(\mathrm{t}) ; \mathrm{t} \geq 0\right\}$ represent the value accumulation process of the fund considering advance yearly fixed withdrawals of $R$. The initial investment budget in $t=0$ is $C$, which results in $V_{0}$ $=\mathrm{C}-\mathrm{R}$. The capital that is available at the beginning of the investment period (after withdrawal of the pension payment) is invested with the proportion $\mathrm{x}_{\mathrm{E}}\left(0 \leq \mathrm{x}_{\mathrm{E}} \leq 1\right)$ in a stock fund and to a complementary proportion $1-\mathrm{x}_{\mathrm{E}}$ in a bond fund. Assuming an initial (front load) issuing surcharge of $100 \mathrm{a}_{\mathrm{E}} \%$ for stock funds and of $100 \mathrm{a}_{\mathrm{B}} \%$ for bond funds, this results in an amount of $\mathrm{x}_{E}(\mathrm{C}-\mathrm{R}) /\left(1+\mathrm{a}_{\mathrm{E}}\right)+\left(1-\mathrm{x}_{\mathrm{E}}\right)(\mathrm{C}-\mathrm{R}) /\left(1+\mathrm{a}_{\mathrm{B}}\right)$ available for investment, i.e. the starting value in this case is $\mathrm{V}_{0}=\mathrm{x}_{\mathrm{E}}(\mathrm{C}-\mathrm{R}) /\left(1+\mathrm{a}_{\mathrm{E}}\right)+\left(1-\mathrm{x}_{\mathrm{E}}\right)(\mathrm{C}-\mathrm{R}) /\left(1+\mathrm{a}_{\mathrm{B}}\right)$.

We take the standard-approach where the value development of stock and bond funds follows a two-dimensional geometric Brownian motion. Letting $I_{E}(t)$ resp. $I_{B}(t)$ represent the respective continuous one-period returns, then for the process $\left\{S_{E}(t)\right\}$ of the development of the stock fund we get

$$
\mathrm{S}_{\mathrm{E}}(\mathrm{t})=\mathrm{S}_{\mathrm{E}}(\mathrm{t}-1) \cdot \exp \left\{\mathrm{I}_{\mathrm{E}}(\mathrm{t})\right\}
$$

and correspondingly, for the process of the development of the bond fund

$$
\mathrm{S}_{\mathrm{B}}(\mathrm{t})=\mathrm{S}_{\mathrm{B}}(\mathrm{t}-1) \cdot \exp \left\{\mathrm{I}_{\mathrm{B}}(\mathrm{t})\right\}
$$

Assuming a static asset allocation over time, which implies that the portolio is rebalanced to maintain the original investment weights, the total value of the investment account is given by:

$$
\mathrm{V}(\mathrm{t}+1)=\mathrm{V}(\mathrm{t}) \cdot\left[\mathrm{x}_{\mathrm{E}} \cdot \exp \left\{\mathrm{I}_{\mathrm{E}}(\mathrm{t}+1)\right\}+\left(1-\mathrm{x}_{\mathrm{E}}\right) \cdot \exp \left\{\mathrm{I}_{\mathrm{B}}(\mathrm{t}+1)\right\}\right]-\mathrm{R}
$$

The generation of the paths of the process of development of the invested capital can therefore be based of the successive (simultaneous) generation of realizations of $\left[\mathrm{I}_{\mathrm{E}}(\mathrm{t}+1), \mathrm{I}_{\mathrm{B}}(\mathrm{t}+1)\right](\mathrm{t}=$ $0,1,2, \ldots$,$) . In the case of a bivariate geometric Brownian motion it is known that \left[\mathrm{I}_{\mathrm{E}}(\mathrm{t}), \mathrm{I}_{\mathrm{B}}(\mathrm{t})\right]$ represent independent realizations of a bivariate normally distributed vector $\left(\mathrm{I}_{\mathrm{E}}, \mathrm{I}_{\mathrm{B}}\right)$ of random variables. The corresponding parameters have to be identified empirically (cf. Table 2). 


\section{References}

Ameriks, J.; R. Veres and M.J. Warshawsky (2001): Making Retirement Income Last a Lifetime, Journal of Financial Planning, December 2001, 1 - 14.

Artzner, P.; F. Delbaen; J.-M. Eber and D. Heath (1999): Coherent Measures of Risk, Mathematical Finance 9, 203 - 238.

Bengen, W.P. (1997): Conserving Clients Portfolios During Retirement, Journal of Financial Planning, December 1997, 84 - 97.

Brown, J.R.; O.S. Mitchell and J.M. Poterba (1999): The Role of Real Annuities and Indexed Bonds in an Individual Accounts Retirement Program, in: J.M. Campbell and M. Feldstein (ed.), Risk Aspect of Investment-Based Social Security Reform (National Bureau of Economic Research conference report), 2001, 321-369.

Hallman, G.V. and J.S. Rosenbloom (2000): Personal Financial Planning, New York.

Hoem, J. (1988): The versatility of the Markov chain as a tool in the mathematics of life insurance, Transactions of the $23^{\text {rd }}$ International Congress of Actuaries, Vol. 12, 171202.

Linneman, P. (2002): Comparison of the net premium and paid-up benefit valuation principles, Blätter der Deutschen Gesellschaft für Versicherungsmathematik, Vol. XXV, April 2002, 629-647.

Ljung, G. and Box, G. (1979): On a Measure of Lack of Fit in Time Series Models, Biometrika 66, 265-270.

Maurer, R. and S.P. Sebastian (2001): Inflation Risk Analysis of European Real Estate Securities, Working Paper Finance \& Accounting No. 52, University of Frankfurt/M. (forthcoming in: Journal of Real Estate Research)

Milevsky, A.M. (1998): Optimal Asset Allocation Towards The End of the Life Cycle: To Annuitize or Not to Annuitize ?, Journal of Risk and Insurance 65, 401-426.

Milevsky, A.M. (2001): Optimal Annuitization Policies: Analysis of the Options, North American Actuarial Journal 5, 57-69.

Milevsky, A.M.; K. Ho and C. Robinson (1997): Asset Allocation Via the Conditional First Exit Time or How to Avoid Outliving Your Money, Review of Quantitative Finance and Accounting 9, 53-70.

Milevsky, A.M. and C. Robinson (2000): Self-Annuitization and Ruin in Retirement, North American Actuarial Journal 4, 113-129.

Mitchell, O.S.; J.M. Poterba; M. J. Warshawsky and J.R. Brown (1999): New Evidence on the Money's worth of Individual Annuities, American Economic Review, December 1999, 1299-1318. 
Pye, G.B. (2000): Sustainable Investment Withdrawals, Journal of Portfolio Management, Summer 2000, $73-83$.

Pye, G.B. (2001): Adjusting Withdrawal Rates for Taxes and Expenses, Journal of Financial Planning, April 2001, 126 - 136.

Ramlau-Hansen, H. (1991): Distribution of surplus in life insurance, ASTIN Bulletin 21, 5771.

Schmithals, B. and E.U. Schütz (1995): Herleitung der DAV-Sterbetafel 1994 R für Rentenversicherungen, Blätter der Deutschen Gesellschaft für Versicherungsmathematik XXII, April 1995, 29-69. 


\section{TABLES}

Table 1: Immediate Yearly Life-long Annuity Payout per EUR 100 Single Premium (Terminal Age 110; total expense loadings 7.12\%)

\begin{tabular}{|c|c|c|c|}
\hline Interest Rate & $\mathbf{4 \%}$ & $\mathbf{5 . 5 \%}$ & $\mathbf{7 \%}$ \\
\hline Entry Age & \multicolumn{3}{|c|}{ Life Annuity (EUR p.a.) } \\
\hline $\mathbf{6 0}$ & 6.23465 & 7.17664 & 8.14253 \\
\hline $\mathbf{6 5}$ & 7.06501 & 7.99189 & 8.93636 \\
\hline $\mathbf{7 0}$ & 8.24026 & 9.15922 & 10.0885 \\
\hline
\end{tabular}

Table 2: Descriptive Statistics for Stocks, Bonds and Real-Estate Funds

\begin{tabular}{|c|c|c|c|c|c|}
\hline \multirow[t]{2}{*}{ Class of Fund } & \multirow{2}{*}{$\begin{array}{l}\text { Mean return } \\
\quad(\% \text { p.a })\end{array}$} & \multirow{2}{*}{$\begin{array}{l}\text { Volatility } \\
\text { (\% p.a.) }\end{array}$} & \multicolumn{3}{|c|}{ Correlations } \\
\hline & & & Stocks & Bonds & Real-estate \\
\hline Stocks & 11.78 & 16.78 & 1 & & \\
\hline Bonds & 7.52 & 5.02 & 0.335 & 1 & \\
\hline Real-estate & 6.62 & 1.78 & -0.247 & 0.353 & 1 \\
\hline
\end{tabular}

\begin{tabular}{|c|c|c|c|c|c|}
\hline \multirow{2}{*}{$\begin{array}{c}\text { Entry } \\
\text { Age }\end{array}$} & \multirow{2}{*}{$\begin{array}{c}\text { Yield } \\
\end{array}$} & \multirow{2}{*}{$\begin{array}{c}\text { PCS } \\
(\boldsymbol{\%})\end{array}$} & \multicolumn{3}{|c|}{ Investment weights (\%) in } \\
\cline { 4 - 7 } & & & Stocks & Bonds & Real-estate \\
\hline \multirow{3}{*}{60} & 4.0 & 0.15 & 10 & 0 & 90 \\
\cline { 2 - 6 } & 5.5 & 4.96 & 35 & 15 & 50 \\
\cline { 2 - 6 } & 7.0 & 14.18 & 50 & 30 & 20 \\
\hline \multirow{3}{*}{65} & 4.0 & 2.16 & 25 & 10 & 65 \\
\cline { 2 - 6 } & 5.5 & 9.07 & 50 & 35 & 0 \\
\cline { 2 - 6 } & 7.0 & 17.50 & 80 & 20 & 15 \\
\hline 70 & 4.0 & 7.14 & 50 & 35 & 0 \\
\cline { 2 - 6 } & 5.5 & 14.0 & 75 & 25 & 0 \\
\cline { 2 - 6 } & 7.0 & 21.39 & 100 & 0 & 0 \\
\hline
\end{tabular}

Table 3: PCS and corresponding risk minimizing fund allocation for a pensioner with entryage 60-, 65- and 70 dependent on interest rate for annuity calculation 


\begin{tabular}{|c|c|c|}
\hline Investment weights & Interest Rate + & Entry-age + \\
\hline Stocks & + & + \\
\hline Bonds & $+/-$ & $+/-$ \\
\hline Real-estate & - & - \\
\hline
\end{tabular}

Table 4: Stocks, bonds and realestate fund proportion for varying entry-ages and second order interest rates chosen for annuity calculation

Table 5: Descriptive Statistics for the Investment Returns for German Life Insurers

\begin{tabular}{|l|c|c|c|}
\hline \multirow{2}{*}{} & \multicolumn{3}{|c|}{ Insurance Company with the ... mean return (1980-1998) } \\
\cline { 2 - 4 } & lowest & median & highest \\
\hline M ean return (\% p.a.) & 6.85 & 7.17 & 7.50 \\
\hline V olatility (\% p.a.) & 0.25 & 0.44 & 0.86 \\
\hline Sample autocorrelation & $0.30^{*}$ & $0.42^{*}$ & $0.59^{*}$ \\
\hline
\end{tabular}

Sample autocorrelation marked with an asterisk are statistically significant at the $5 \%$ level according to the $Q$ statistic of Ljung/Box 1979.

\begin{tabular}{|c|c|c|c|}
\hline Table 6: Annuity-Certain (terminal age 110; EUR 100 single premium) \\
\hline Interest Rate (\%p.a.) & $\mathbf{4}$ & $\mathbf{5 . 5}$ & $\mathbf{7}$ \\
\hline Age & \multicolumn{3}{|c|}{ Term Certain Annuity p.a. } \\
\hline $\mathbf{6 0}$ & 4.4799 & 5.5982 & 6.7719 \\
\hline $\mathbf{6 5}$ & 4.6406 & 5.7281 & 6.8691 \\
\hline $\mathbf{7 0}$ & 4.8580 & 5.9071 & 7.0102 \\
\hline
\end{tabular}




\section{FIGURES}

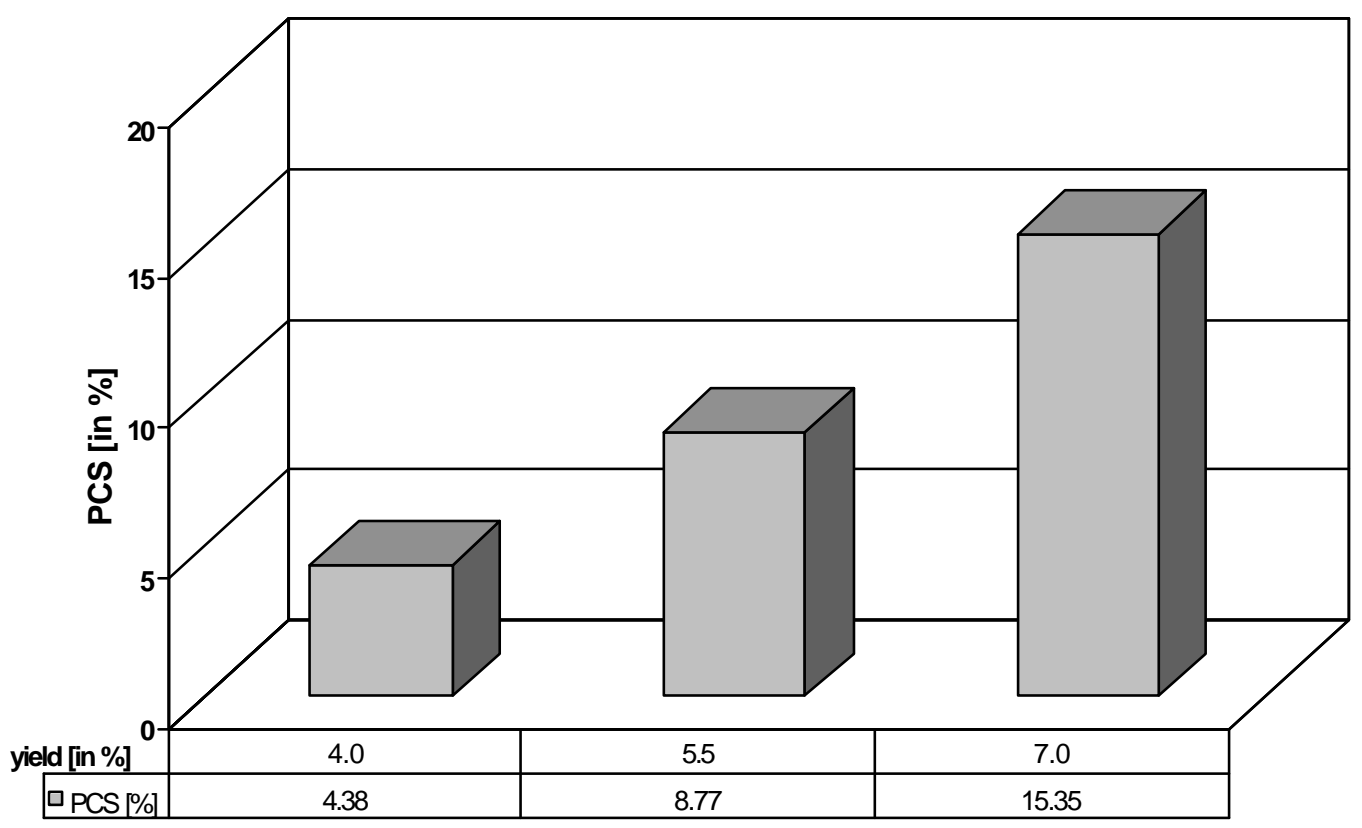

Figure 1: Probabilities of consumption shortfall in retirement (PCS) of a 60-year old man in the case of a equity fund investment dependent on interest rate for annuity calculation

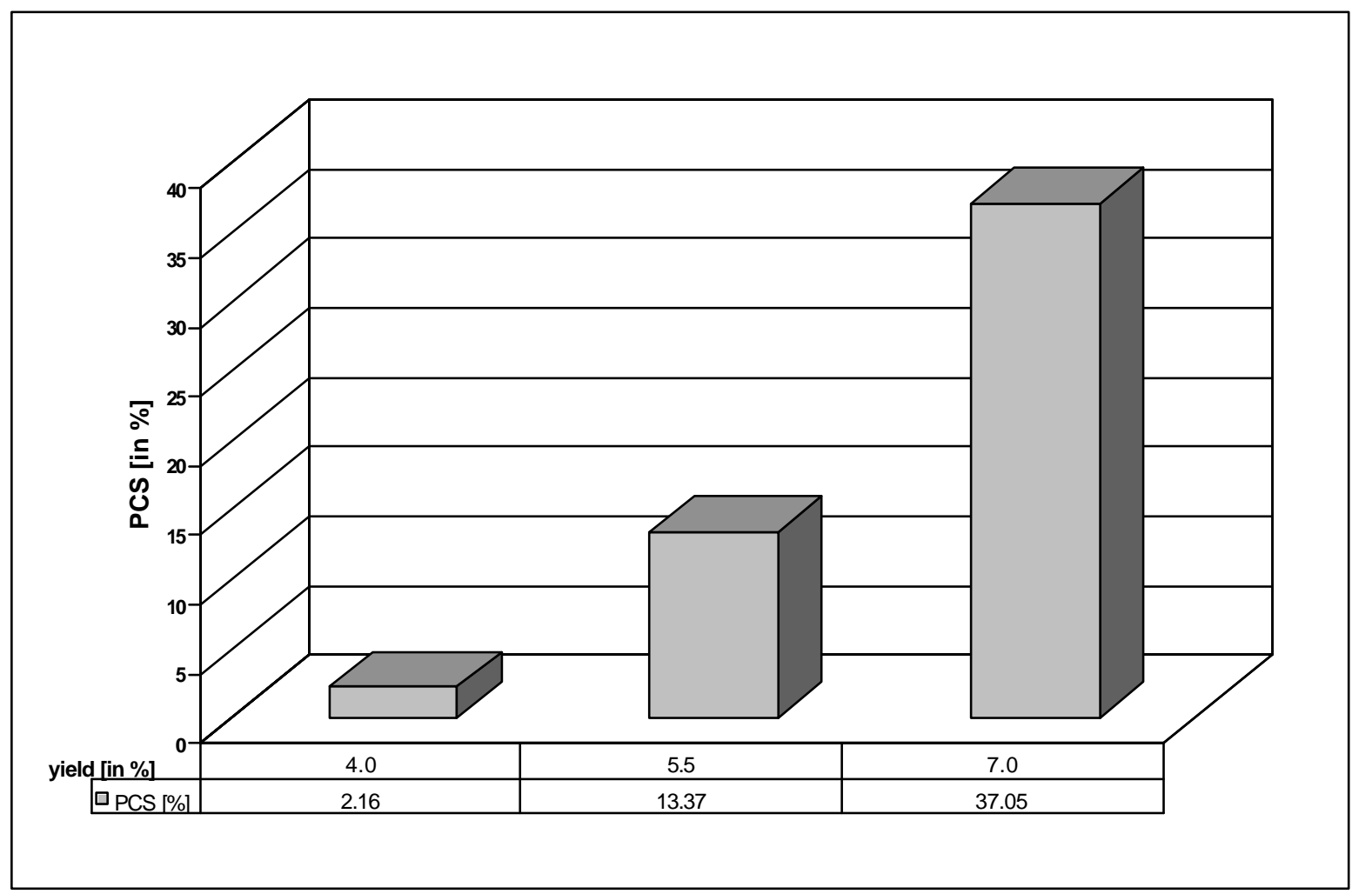

Figure 2: Probabilities of consumption shortfall in retirement (PCS) of a 60-year old man in the case of a bond-fund investment dependent on interest rate for annuity calculation 


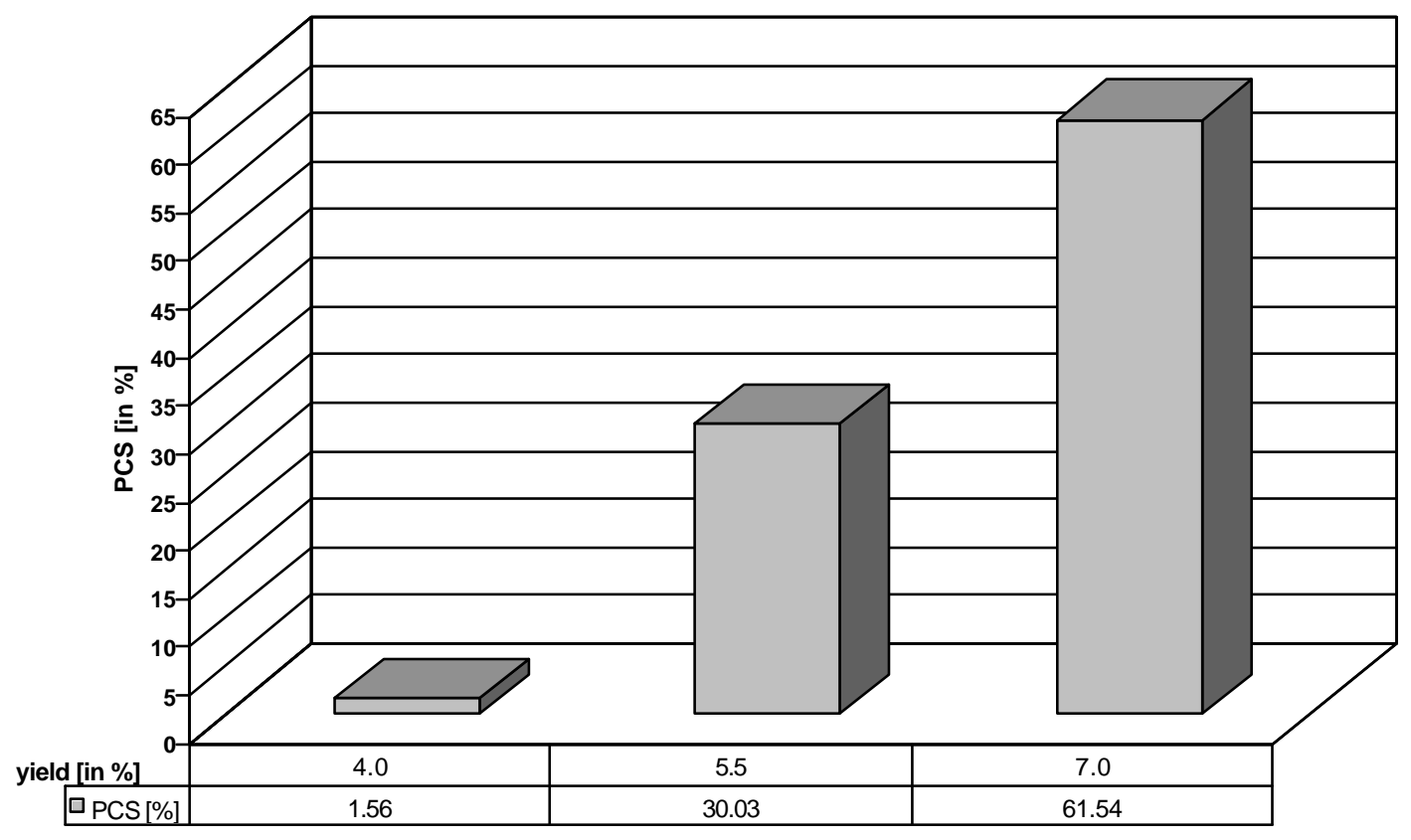

Figure 3: Probabilities of consumption shortfall in retirement (PCS) of a 60-year old man in the case of a real estate investment dependent on interest rate for annuity calculation

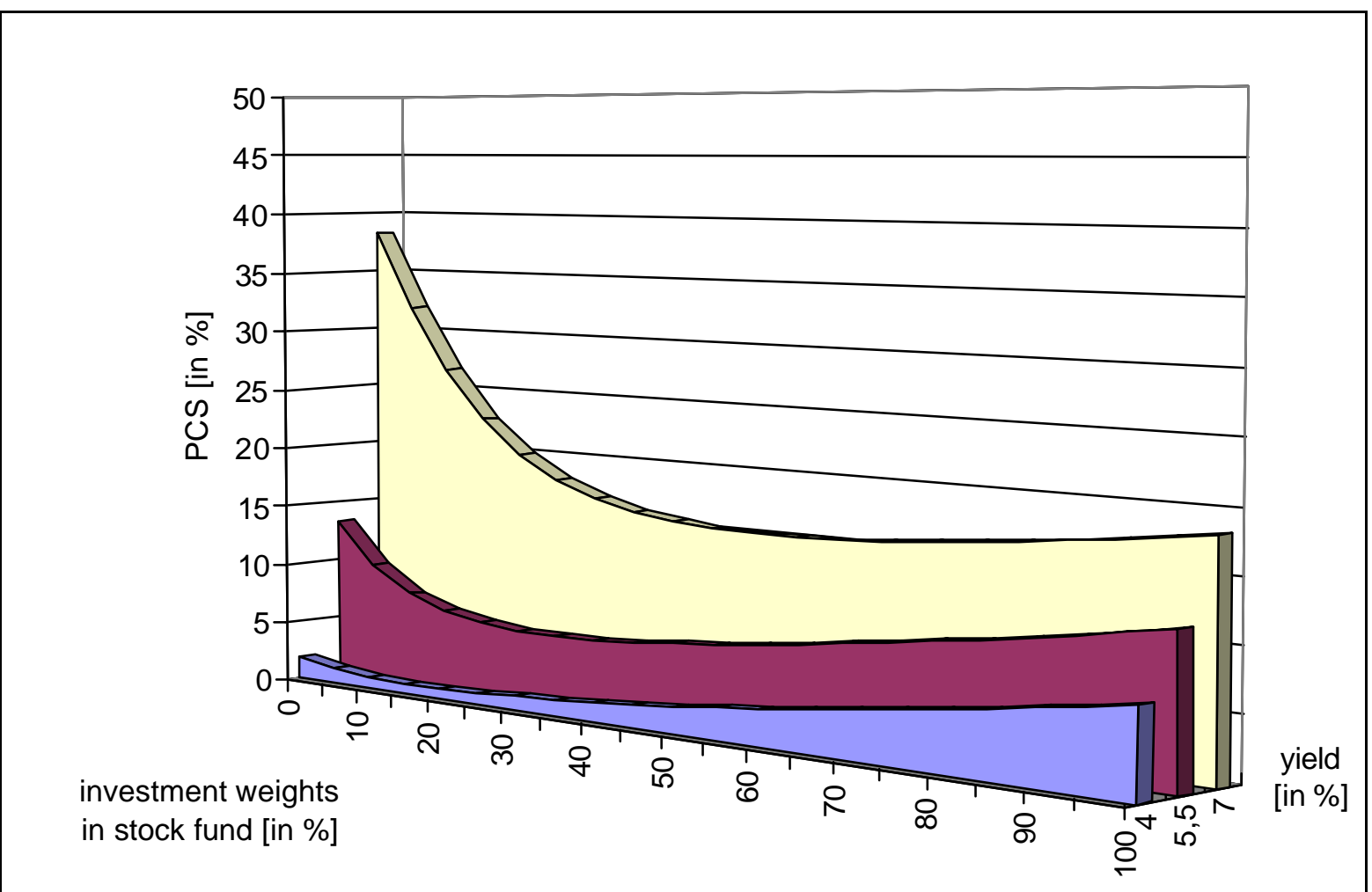

Figure 4: Probabilities of consumption shortfall in retirement for a 60-year old man with alternative stock and bond investments [in \%] dependent on interest rate for annuity calculation 


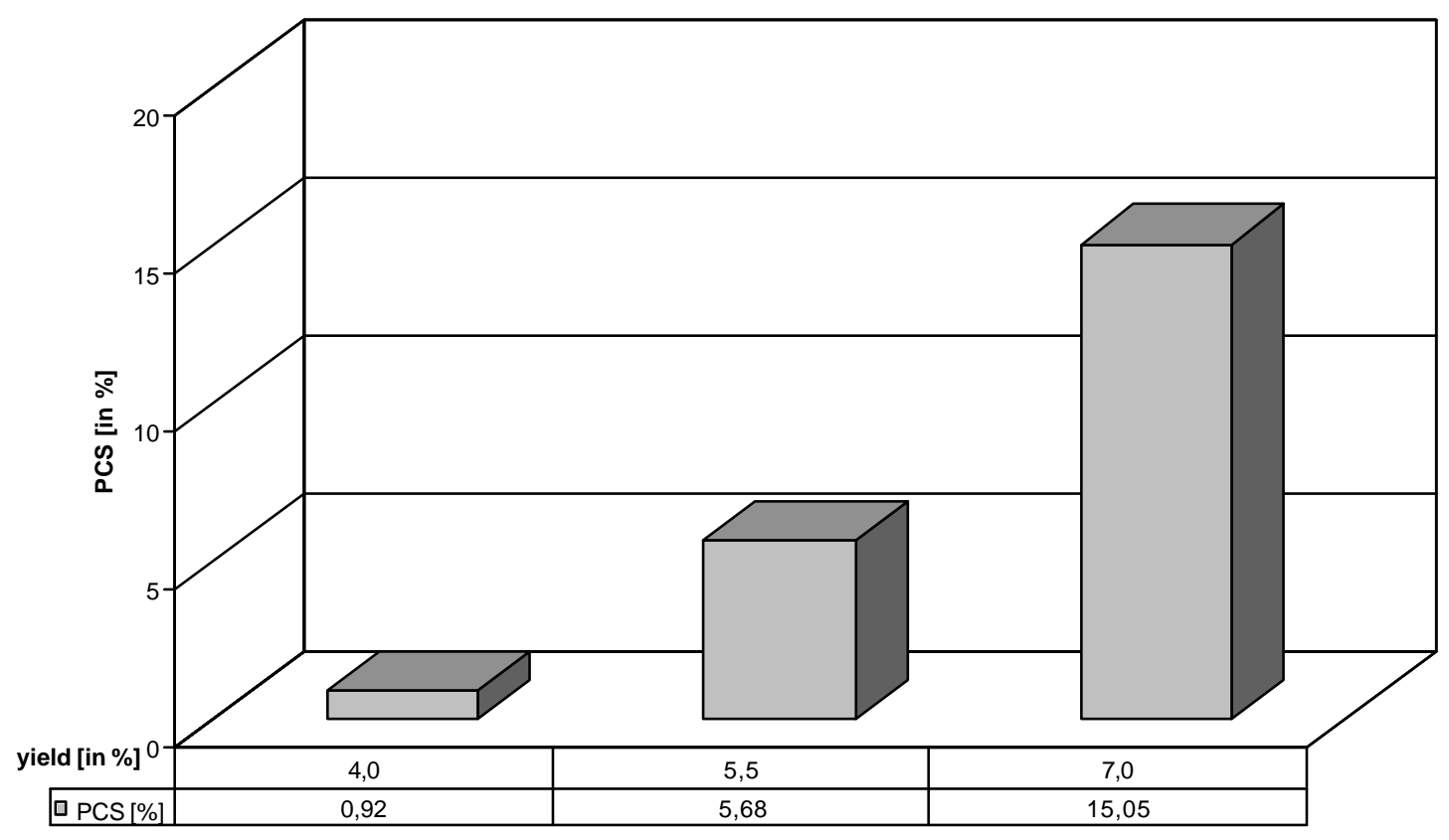

Figure 5: Probabilities of consumption shortfall in retirement for a 60-year old man with a risk minimizing stock/bond-fund allocation dependent on interest rate for annuity calculation

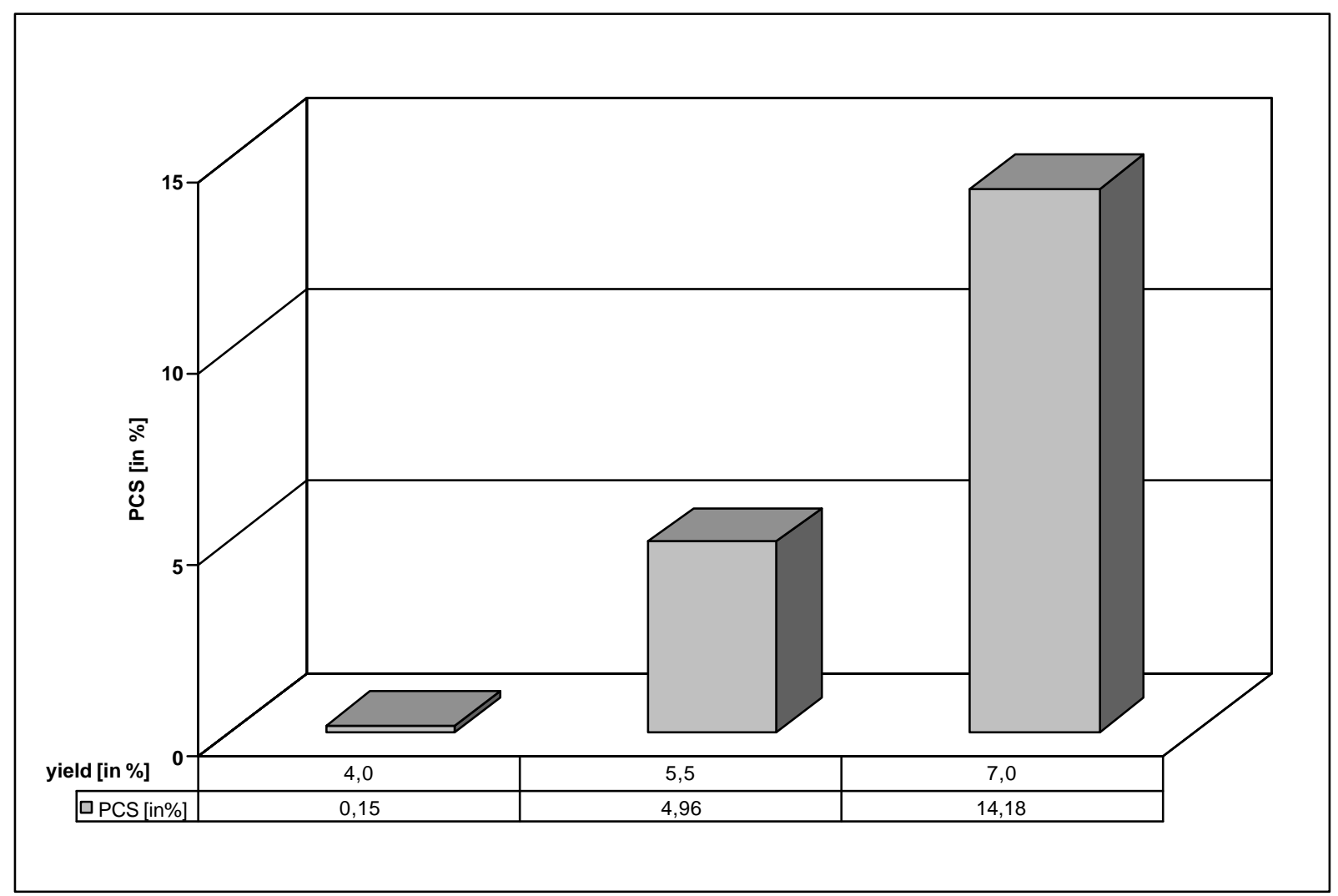

Figure 6: Probabilities of consumption shortfall in retirement for a 60-year old man with a risk minimizing stock/bond/real-estate fund allocation dependent on interest rate for annuity calculation 


\section{ENDNOTES}

1) See Brown/Mitchell/Poterba (1999).

2) There are other types of annuities contracts with longer payout durations or certain death benefits, but lower income payments. E.g., in the case of a joint-and-survivor annuity payments continue as long as one member of the couple is alive. Death benefits are frequently offered in connecting with a guaranteed period over which benefits will be paid even if the annuitant does not survive. See Hallman/Rosenbloom (2000), 435448.

3) The expression "self-annuitization" was created by Milevsky/Robinson (2000).

4) Cf. especially Ameriks/Veres/Warshawsky (2001), Bengen (1997), Milevsky/Ho/Robinson (1997), Milevsky/Robinson (2000) and Pye (2000, 2001).

5) Other objectives, which are not considered in the paper, would be to determine the optimal point of time to annuitize resp. to consider combinations of a self-annuitization strategy and an annuity. Cf. eg. Ameriks/Veres/Warshawsky (2001) and Milevsky (1998, 2001).

6) A more general risk measure ("tail conditional expectation") would be to calculate the mean amount of consumption shortfall, given that a consumption shortfall occurs. This risk measure, which was proposed recently by Artzner et al. (1999) has some favourable structural properties ("coherence"). However, besides the computational problem, we feel that the probability of consumption shortfall is of predominant interest for the retiree.

7) For a technical elaboration of the „safe side requirement“ cf. Hoem (1988, p. 189).

8) The costs of providing this guarantee are twofold. First of all the mean return on the insurers assets is somewhat lower than the mean return on the bond market (compare the results of section 3.4 with table 2). Second, as already mentioned in the introduction, there is a serious loss of liquidity for the buyer of the annuity contract.

9) For methods of surplus distribution in life insurance cf. e.g. Ramlau-Hansen (1991).

10) For a discussion of technical bases of first and second order cf. the recent contribution of Linneman (2002).

11) This assumption has the effect, that the capital left to grow is immediately reduced. However, this assumption is corresponding to the usual market conditions in Germany.

12) See Appendix B for technical details. In addition we run simulations using historical annual returns randomly scrambled according to a bootstrap statistical approach. The (not reported) results are very close to the Monte-Carlo-Simulations presented here.

13) Milevsky/Robinson (2000) have developed an analytical approximation method based on moment-matching techniques and the reciprocal gamma distribution and therefore can avoid Monte Carlo-simulation.

14) Administrative ost and investment fees can be charged directly by the mutual funds company from the assets of the fund. Therefore, the observed returns of the different mutual funds reflect such costs.

15) As noted by Maurer/Sebastian (2001) the returns of German real estate mutual funds are also due to appraisal smoothing.

16) This also has the consequence, that the results will be in general not compatible with an utility maximizing framework. 